\title{
THE USE OF NEW ECOLOGICAL PARADIGM SCALE AMONG PRE-SERVICE PRIMARY TEACHERS: LIMITS AND POSSIBILITIES
}

\author{
Roman Kroufek $^{1 \star}$, Vlastimil Chytrý ${ }^{2}$, Jan Janovec ${ }^{3}$, Ivana Brtnová Čepičkováa \\ ${ }^{1}$ Asst. Prof., The University of J. E. Purkyně, CZECH REPUBLIC, roman.kroufek@ujep.cz \\ ${ }^{2}$ Asst. Prof. Dr., The University of J. E. Purkyně, CZECH REPUBLIC, vlastimil.chytry@ujep.cz \\ ${ }^{3}$ Asst. Prof. Dr., The University of J. E. Purkyně, CZECH REPUBLIC, jan.janovec@ujep.cz \\ ${ }^{4}$ Assoc. Prof. Dr., The University of J. E. Purkyně, CZECH REPUBLIC, ivana.brtnova- \\ cepickova@ujep.cz \\ ${ }^{*}$ Corresponding Author
}

\begin{abstract}
Assessment and measurement of attitudes towards environmental issues is an important task of environmental education and one of the ways of its evaluation, focused on the affective component of environmental literacy. A wide range of research tools and scales is used for the measurement of proenvironmental attitudes in quantitative way. The best known and most widely used both in the world and in the Czech Republic is the New Environmental Paradigm (Dunlap \& Van Liere, 1978) or New ecological paradigm (Dunlap et al. 2000), which has been modified several times and was used to detect environmental attitudes among various demographic groups. One of these are teachers and pre-service teachers (student teachers), who bear the major responsibility for the attitudes of the pupils. It is, therefore important to be able to identify environmental attitudes of students and teachers to assess the impacts of environmental action in their previous life and during their studies at universities. In the paper, we describe the possibilities of verifying the new ecological paradigm scale among pre-service primary teachers from the Czech Republic. The primary objective is to determine what are the possibilities and limits of this research tool and its subscales. We focused on reliability and construct validity of the scale. Furthermore, we investigate what effects have selected socio-demographic variables (age, gender, type of study) on those attitudes. New ecological paradigm scale as a whole is useful to identify the attitudes of pre-service teachers (Cronbach's $\alpha$ $=.79$ ), but its individual subscales are not applicable by themselves. That is also confirmed by item analysis of the scale. We discuss the possible problems of the use of the scale among pre-service primary teachers.
\end{abstract}

Keywords: environmental attitudes, environmental literacy, new ecological paradigm, pre-service teachers

\section{INTRODUCTION}

The affective component of environmental literacy, in its definition (Hollweg et al., 2011) known as Dispositions is a common target of researchers. They focus primarily on the individuals' relationship to nature and the environment and on environmental attitudes. The most commonly used (Dunlap, 2008) and one of 
the oldest instrument for assessing attitudes towards the environment is a New Environmental Paradigm (Dunlap \& Van Liere, 1978), and its updated version, the New Ecological Paradigm - NEP (Dunlap et al., 2000).

The revisited NEP scale consists of fifteen items the respondent expresses the degree of agreement on a Likert scale. The respondent expresses his/her inclination to the Dominant social paradigm or to the New Environmental Paradigm (Dunlap et al., 2000). The scale is one-factor (for list of items see Table 2), but consist of five dimensions: Balance of nature, Ecocrisis, Antiexemprionalism, Limits to growth and Antianthropocentrism (Dunlap et al., 2000; Amburgey \& Toman, 2011). The internal structure and the possible use of only some part of the scale is disputed (Edoğan, 2009; Kroufek et al., 2015).

The both versions of the NEP scale are often modified and subjected to criticism (Lalonde \& Jackson, 2002, Dunlap, 2008; Noblet et al., 2013), but still widely used in many research projects in different parts of the world. Corral-Verdugo \& Armendáriz (2000) investigated the possibilities of usage of the original NEP scale among residents of Mexico and found a relatively low reliability $(\alpha=.57)$. Similarly, the NEP scale was tested in Turkey (Edoğan, 2009), and results shows limits of its use in different social and cultural environments. The scale showed low reliability $(\alpha=.53)$ and overall inconsistency (Edoğan, 2009). Six-item version of the scale was used in Bulgaria (Pierce et al., 1987) in three different studies (Bostrom et al., 2006) and the results revealed a significant shift of population to the new environmental paradigm. The same results among American college students were achieved by Rideout et al. (2005). Kancír \& Suchá (2013) used NEP scale as a tool for assessing the effectiveness of environmental education in Slovakia, where the topic of environmental education is discussed mainly in the field of secondary education (Macko et al., 2013) with the focus on its relation with biology and chemistry and facilitation of new educational models (Blahútová et al., 2011; Macko et al. 2012).

The ability to predict the responsible environmental behaviour (REB) in both versions of the NEP and a scale not based on NEP (Cordano \& Frieze, 2002) was studied by Cordano et al. (2003). They found that in most cases, the original NEP correlates with REB better but the best results were achieved with the non-NEP scale. Manoli et al. (2007) suggested the solution for problematic use of the NEP with younger respondents. They created a ten-item modification of the scale and validated it for children aged 10-12 years.

An important positive aspect of the NEP is its relative stability and wide usage, which gives researchers a number of results with which they can compare their findings. The scale can thus play an important role in the validation of other research tools as the reference element.

\section{METHODOLOGY}

\subsection{Participants}

The research included 140 respondents, pre-service teachers of primary school. All of them were students of The University of J. E. Purkyně in Ústí nad Labem, Czech Republic. The students were chosen from both full time $(\mathrm{N}=59)$ and part time (combined) study $(\mathrm{N}=81)$ programs. The average age of respondents was 26.8 years, the youngest student was 19 years old, the oldest one was 53 years old. The gender distribution was, due to the specificity of target group, uneven (9 men and 131 women), so we did not analyse the results in terms of gender distribution of respondents.

\subsection{Research tool}

The research tool was a questionnaire consisting of two segments. The first one contained demographic information about the respondents (gender, age, type of study and type of finished high school). The second segment was New Ecological Paradigm scale (Dunlap et al., 2000) in a modified translation by Činčera \& Štěpánek (2007).

The respondents were answering individual items in a five-level Likert scale (Strongly agree - Mildly agree Unsure - Mildly disagree - Strongly disagree).

\subsection{Statistic}

The results were processed using the software Statistica 12 . The reliability of the tool was determined by calculating Cronbach's $\alpha$. The validity is sufficiently proven by re-use of the scales in research abroad and in the Czech Republic and by the mutual correlation of the NEP and other relevant scales (Kroufek et al., 2015).

The normality of the data distribution was examined using the Shapiro-Wilk test for normality. The data did not have normal distribution $(W=.97, p=.01)$ so we used non-parametric statistic tests. To detect 
correlation of the scales and subscales or single items, the Spearman's Rank Correlation Coefficient was used. For comparison of two variables, the Man-Whitney $U$ test was used. For other analysis of the research tool properties the Factor analysis and the Item analysis was realised.

\section{RESULTS}

For greater clarity, the results are divided into three chapters. Each chapter focuses on specific attribute of the research tool (NEP scale).

\subsection{Reliability}

The following table (Table 1) lists values of reliability of the used scale as well as reliability found in other relevant research, focused on the same target group. Although the NEP is one-factor scale, it consists of five dimensions (Dunlap et al., 2000), so we calculated reliability for each of them as well to discuss their possible use of separate subscales.

Table 1. Reliability of NEP scale and its possible subscales (Cronbach $\alpha$ )

\begin{tabular}{|l|l|l|l|}
\hline Scale / subscale & Current research & Kroufek et al. 2015 & Kroufek 2013 \\
\hline NEP & .79 & .78 & .78 \\
\hline Balance of nature & .38 & .61 & \\
\hline Ecocrisis & .41 & .68 & \\
\hline Antiexemprionalism & .67 & .35 & \\
\hline Limits to growth & .60 & .34 & \\
\hline Antiantrophocentrism & .59 & .60 & \\
\hline
\end{tabular}

As you can see from the Table 1 the reliability of the whole NEP scale is quiet same in three following studies with the pre-service primary teachers. Huge differences can be seen in the reliability of each dimension which makes them unusable separately.

\subsection{Internal consistency}

The table no. 2 shows correlations of each item to the total result of NEP scale. In addition, we included mean of achieved points and standard deviation for each item. The table no. 3 then presents correlations among each dimension and NEP scale.

Table 2. Item - NEP correlations (all correlations except the item no. 6 are significant at a level $p<.05$ )

\begin{tabular}{|l|l|l|l|}
\hline Item of the NEP scale & $\begin{array}{l}\text { Correlation: item- } \\
\text { NEP }\end{array}$ & Mean & $\begin{array}{l}\text { Standard } \\
\text { deviation }\end{array}$ \\
\hline $\begin{array}{l}\text { 1. We are approaching the limit of the number } \\
\text { of people the earth can support. }\end{array}$ & .54 & 3.52 & 1.03 \\
\hline $\begin{array}{l}\text { 2. Humans have the right to modify the natural } \\
\text { environment to suit their needs. }\end{array}$ & .51 & 4.01 & .94 \\
\hline $\begin{array}{l}\text { 3. When humans interfere with nature it often } \\
\text { produces disastrous consequences. }\end{array}$ & .62 & 3.95 & 1.03 \\
\hline $\begin{array}{l}\text { 4. Human ingenuity will insure that we do not } \\
\text { make the earth unlivable. }\end{array}$ & .52 & 3.29 & 1.03 \\
\hline $\begin{array}{l}\text { 5. Humans are severely abusing the } \\
\text { environment. }\end{array}$ & .58 & 4.29 & .77 \\
\hline $\begin{array}{l}\text { 6. The earth has plenty of natural resources if } \\
\text { we just learn how to develop them. }\end{array}$ & .16 & 2.42 & 1.09 \\
\hline $\begin{array}{l}\text { 7. Plants and animals have as much right as } \\
\text { humans to exist. }\end{array}$ & .48 & 4.47 & .93 \\
\hline $\begin{array}{l}\text { 8. The balance of nature is strong enough to } \\
\text { cope with the impacts of modern industrial } \\
\text { nations. }\end{array}$ & .65 & 3.95 & .85 \\
\hline $\begin{array}{l}\text { 9. Despite our special abilities humans are still } \\
\text { subject to the laws of nature. }\end{array}$ & .45 & 4.19 & .95 \\
\hline $\begin{array}{l}\text { 10. The co-called "ecological crisis" facing } \\
\text { humankind has been greatly exaggerated. }\end{array}$ & .51 & 3.57 & .96 \\
\hline $\begin{array}{l}\text { 11. The earth Is like a spaceship with very } \\
\text { limited room and resources. }\end{array}$ & .50 & 3.69 & 1.22 \\
\hline
\end{tabular}




\begin{tabular}{|l|l|l|l|}
\hline $\begin{array}{l}\text { 12. Humans were meant to rule over the rest } \\
\text { of nature. }\end{array}$ & .58 & 4.10 & 1.05 \\
\hline $\begin{array}{l}\text { 13. The balance of nature is very delicate and } \\
\text { easily upset. }\end{array}$ & .54 & 4.24 & .89 \\
\hline $\begin{array}{l}\text { 14. Humans will eventually learn enough } \\
\text { about how nature works to be able to control it. }\end{array}$ & .38 & 2.91 & .91 \\
\hline $\begin{array}{l}\text { 15. If things continue on their present course, } \\
\text { we will soon experience a major ecological } \\
\text { catastrophe. }\end{array}$ & 60 & 3.82 & .91 \\
\hline
\end{tabular}

The table shows high correlation of each item of NEP scale with the total result. The correlations are moderate - strong positive, except the item no. $6(r=.16)$. This item has also the lowest achieved mean score from all of the items. The reason of this result is probably in the translation from English to Czech language, or, in more general, the cultural differences. Respondents from the Czech Republic maybe see this statement more as the positive one.

Table 3. Correlations among dimensions and NEP (all correlations are significant at a level $p<.05$ ).

\begin{tabular}{|l|l|l|l|l|l|l|}
\hline & NEP & $\begin{array}{l}\text { Balance } \\
\text { of nature }\end{array}$ & Ecocrisis & $\begin{array}{l}\text { Antiexemprio } \\
\text { nalism }\end{array}$ & $\begin{array}{l}\text { Limits to } \\
\text { growth }\end{array}$ & $\begin{array}{l}\text { Antiantropho } \\
\text { centrism }\end{array}$ \\
\hline NEP & & .80 & .72 & .62 & .59 & .73 \\
\hline Balance of nature & .80 & & .60 & .41 & .31 & .52 \\
\hline Ecocrisis & .72 & .60 & & .31 & .26 & .44 \\
\hline Antiexemprionalism & .62 & .41 & .31 & & .24 & .43 \\
\hline Limits to growth & .59 & .31 & .26 & .24 & & .24 \\
\hline Antiantrophocentrism & .73 & .52 & .44 & .43 & .24 & \\
\hline
\end{tabular}

All dimensions have positive correlation with the NEP scale, three of them strong, two moderate.

The results of the component analysis (see Fig. 1) shows, that the first factor explains $28.57 \%$ of the total variance among the items, the second one then $9.46 \%$.

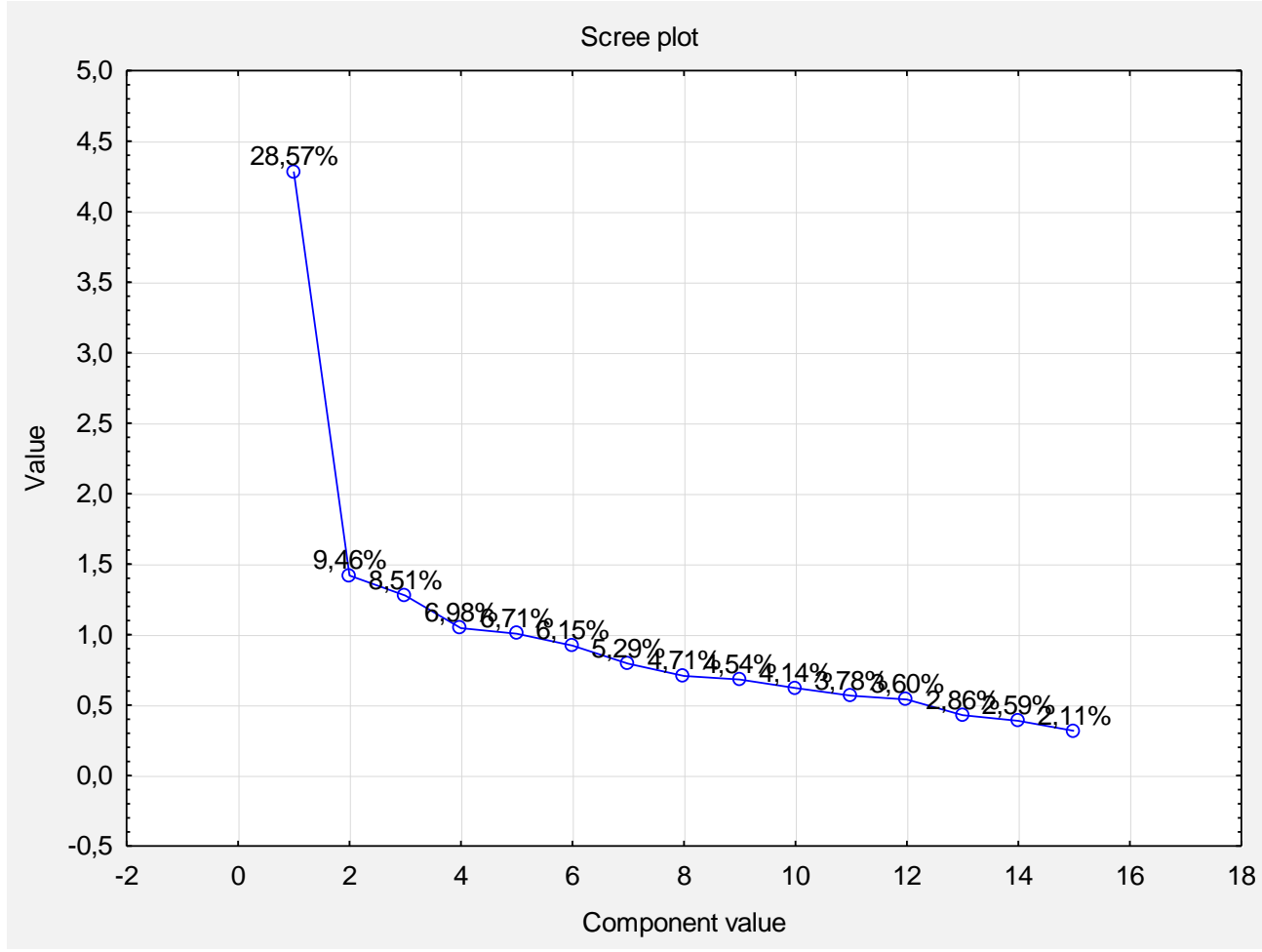

Fig. 1. Scree plot showing the variance explained by each factor.

For each dimension, the respondent can achieve from 3 to 15 points. The Fig. 2 shows the distribution of the achieved points in each dimension. The median was never lower than 10. 


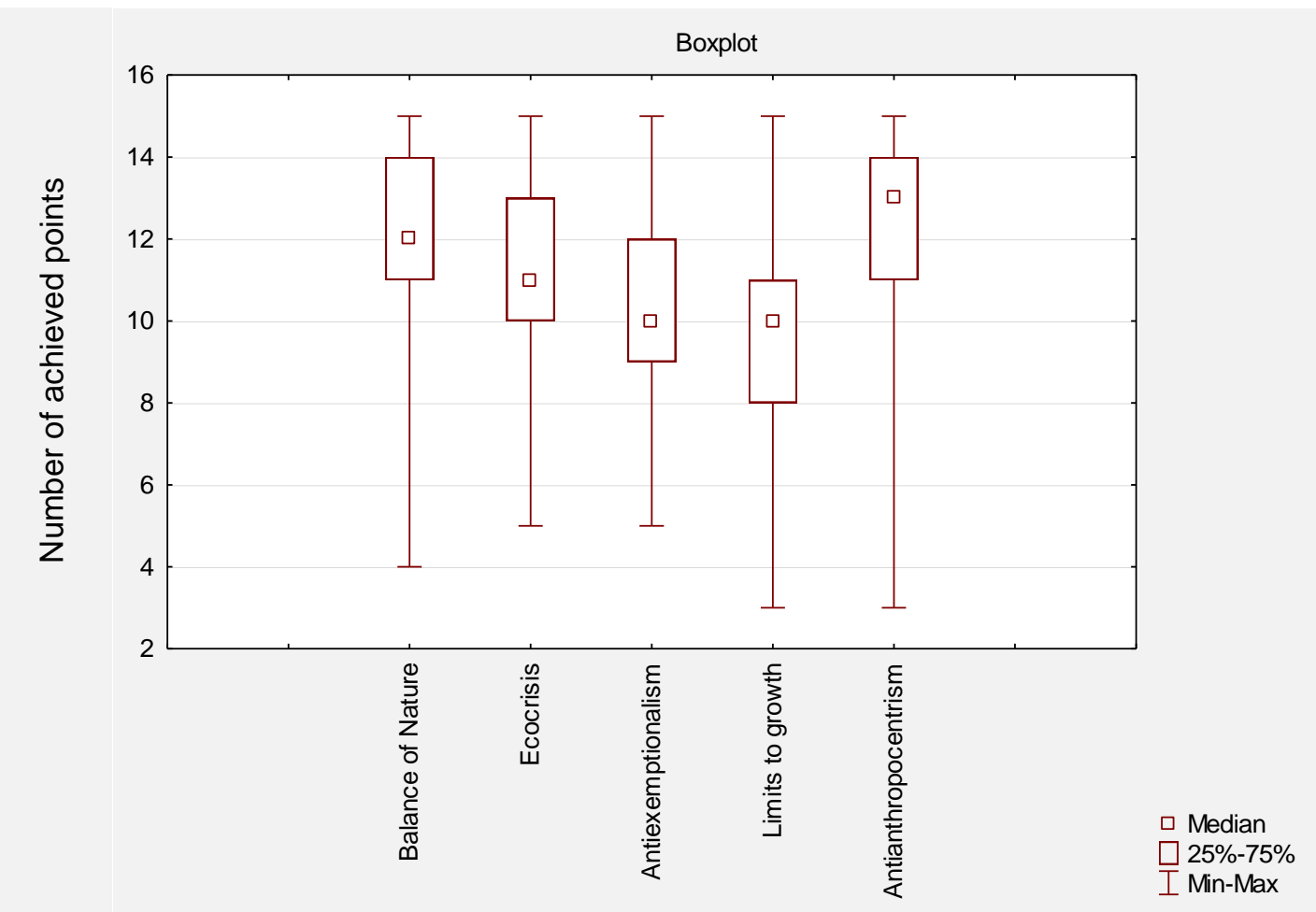

Fig. 2. Boxplot for each dimension, showing distribution of achieved points.

\subsection{Demographic data}

After the research tool investigation, we performed some tests based on different demographic data of the respondents. The age of the respondents significantly correlated only with the dimension Antiantrophocentrism, the correlation was weak positive $(r=.17)$. The variable "type of study" showed no statistically significant difference $(Z=.97, p=.33)$.

\section{CONCLUSION}

The results show that the use of the New Ecological Paradigm scale among pre-service primary teachers is particularly problematic. The scale has very good and in-time stable reliability (see Table 1), that is close to the original one $(\alpha=.83)$ achieved by Dunlap et al. (2000). We also agree with the fact that the NEP is a single-factor scale (see Fig. 1.). Internal consistency of the scale is very good, except for item $6(r=.16)$ all other items have a correlation with the total results higher than $r=.38$, the mean correlation is $r=.51$. We do not recommend using separate parts of NEP because of the low reliability (see Table 1).

So the reliability of the scale is very good, the scale focus more or less on one factor and where is the problem? We see the problem in the fact, that almost all of the respondents have their worldview close to the New Environmental Paradigm so it is no more "new" worldview and it becomes a standard. The mean of six items of the scale is higher than 4 (out of 5 possible points) and four more item have mean close to 4 points. Only two items score was lower than 3 . It is shown the most importantly on the dimension Antiantrophocentrism (see Fig. 2) with the mean 12.58 (from range 3 - 15).

It seems that either the pre-service primary teachers are specific group with a high inclination to the ideas of $\mathrm{NEP}$, or that these ideas become standard of the society and, regarding the environmental attitudes, instead of NEP scale, the researchers should focus on some more sensitive one.

\section{ACKNOWLEDGEMENT}

The paper was supported by the Grant Agency of the J. E. Purkyně University in Ústí nad Labem, grant SGS "The Analysis of relationship between technological and environmental literacy of pre-service primary teachers." 


\section{REFERENCE LIST}

Amburgey, J. W. \& Thoman, D. B. (2011). Dimensionality of the New Ecological Paradigm: Issues of Factor Structure and Measurement. Environment and Behavior, 44(2). DOI: 10.1177/0013916511402064

Blahútová, D., Macko, J. \& Stollárová, N. (2011). Multimedia Elements in Biology and Chemistry Education. Informatologia, 44(4).

Bostrom, A., Barke, R., Turaga, R. M. R. \& O'Connor, R. E. (2006). Environmental Concerns and the New Environmental Paradigm in Bulgaria. The Journal of Environmental Education, 37(3). DOI: 10.3200/JOEE.37.3.25-40

Cordano, M. \& Frieze, I. H. (2002). Enhancing environmental management teaching through applications of toxic release information. In: Sharma, S. \& Starick, M. [eds.] Research on corporate sustainability. New York: Edwar Elgar Publications.

Cordanu, M., Welcomer, S. A. \& Scherer, R. F. (2003). An Analysis of the Predictive Validity of the New Ecological Paradigm Scale. The Journal of Environmental Education, 34(2). DOI: $10.1080 / 00958960309603490$

Corral-Verdugo, V. \& Armendariz (2000). The "New Environmental Paradigm" in a Mexican community. The Journal of Environmental Education, 31(3). DOI: 10.1080/00958960009598642

Činčera, J., \& Štěpánek, P. (2007). Výzkum ekologické gramotnosti studentů středních odborných škol. Envigogika, 2(1). DOI: 10.14712/18023061.12

Dunlap, R. E. (2008). The New environmental paradigm scale: From marginality to worldwide use. The Journal of Environmental Education, 4O(1). DOI: 10.3200/JOEE.40.1.3-18

Dunlap, R. E., \& Van Liere, K. D. (1978). The new environmental paradigm: A proposed measuring instrument and preliminary results. The Journal of Environmental Education, 9(4). DOI: 10.1080/00958964.1978.10801875

Dunlap, R. E., Van Liere, K. D., Mertig, A. G., \& Jones, R. E. (2000). Measuring endorsement of the New Ecological Paradigm: a revised NEP scale. The Journal of Social Issues, 56(3). DOI: 10.1111/00224537.00176

Edoğan, N. (2009). Testing the new ecological paradigm scale: Turkish case. African Journal of Agricultural Research, 4(10).

Hollweg, K. S. Taylor, J. R., Bybee, R. W., Marcinkowski, T. J., McBeth, W. C., \& Zoido, P. (2011). Developing a framevork for assessing environmental literacy. Washington, DC: North American Association for Environmental Education.

Kancír, J. \& Suchá, I. (2013). Škála Novej environmentálnej paradigmy ako výskumný nástroj v oblasti environmentálnej gramotnosti. Aktuálne otázky prírodovedno-technických predmetov a prierezových tém v primárnej edukácii. Online konferencia 23. - 25. 10. 2013

Kroufek, R. (2013). Environmentální postoje studentů učitelství pro 1. stupeň ZŠ. - Sborník přispěvků: XXI. celostátní konference ČAPV Efektivita vzdělávání v proměnách společnosti. PF UJEP, Ústí nad Labem.

Kroufek, R., Janovec, J. \& Chytrý, V. (2015). Pre-service primary teachers and their attitudes towards nature. In: Fleischmann, O., Seebauer, R., Zoglowek, H. \& Aleksandrovich, M. [eds.] The Teaching profession: New Challneges - New Identities. Lit Verlag GmbH \& Co. KG, Wien

Lalonde, R. \& Jackson, E. L. (2002). The New Environmental Scale: Has It Outlived Its Usefulness? Journal of Environmental Education, 33(4). DOI:10.1080/00958960209599151

Macko, J., Blahútová, D. \& Stollárová, N. (2012). New Education Model for Information Monitoring of Environment Water Flows. Informatologia, 45(3).

Macko, J., Blahútová, D. \& Stollárová, N. (2013). Space for the Environmental Education in the System of Secondary Education in Slovakia. Informatologia, 46(3).

Manoli, C. C., Johnson, B. \& Dunlap, R. E. (2007). Assessing Children's Environmental Worldviews: Modifying and Validating the New Ecological Paradigm Scale for Use with Children. The Journal of Environmental Education, 38(4). DOI:10.3200/JOEE.38.4.3-13 
Noblet, C. L., Anderson, M. \& Teisl, M. F. (2013). An empirical test of anchoring the NEP scale in environmental ethics. Environmental Education Research, 19(4). DOI: 10.1080/13504622.2012. 704899

Pierce, J. C., Lovrich, N. P., Tsurutani, T. \& Abe, T. (1987). Culture, politics, and mass publics: Traditional and modern supporters of the new environmental paradigm scale in Japan and the United States. The Journal of Politics, 49(1).

Rideout, B. E., Hushen, K., McGinty, D., Perkins, S. \& Tate, J. (2005). Endorsement of the New Ecological Paradigm in Systematic and E-mail Samples of College Students. The Journal of Environmental Education, 36(2). DOI: 10.3200/JOEE.36.2.15-23 